\title{
Basic Party Units and Decentralized Development
}

\author{
THIAGARAJAN MANOHARAN
}

In the first part of this paper ${ }^{1}$ the cadre strength is estimated at 7.04 million (1985), including 1.43 million in the state sector at and below xian level and 1.07 million in the collective sector. ${ }^{2}$

The state civil service emoluments are based on basic wage, the same for the President and the Prime Minister as for the lowest civil servant, plus 12 gradations based on the job responsibilities. ${ }^{3}$ The supervisory personnel starts from the third grade, in an ascending order. There are within the grade increments in six or eight steps, allowances according to the area of posting, cost of living and various subsidies. The maximum salary, exclusive of all the perks and allowances, is 530 yuan and the minimum 52 yuan per month.

At the collective sector, apart from the state cadres, the collective administration fixes the emoluments of the staff it recruits out of the collective sector budget under which administrative expenses are defrayed by various types of levies; requisite data from collective sector budgets are not available. Cadres in the collective enterprises are largely appointed by the collective administration; for cadres who manage or lease the enterprises under contracts, the emoluments are variants of profit-sharing formulae according to the type of contracts, eg. leasing, "economic responsibility," management, science and technology. A few anecdotal accounts indicate that the enterprise cadres enjoy emoluments above those of the leading cadres in the collective administration. However, information and data are required on a larger scale.

Statistical ambiguities notwithstanding, the broadly indicative numerical strength of cadres is impressive, nearly 7 percent of the total staff and workers in all the establishments in the whole country.

Cadre performance and evaluation is reviewed in this paper only 
in terms of abuse of authority and corruption. The two public opinion surveys available indicate that these are the aspects which engage the public's attention most. ${ }^{4}$ Scientific job classification and performance evaluation of the customary kind are at the beginning stage in the administrative system of the People's Republic of China (PRC); the recent reforms, briefly reviewed below, towards internal administrative supervision and control are also oriented towards cadres' abuse of power and corruption. Characteristic of the PRC since Liberation days is the evaluation of cadres' performance by the public and, internally, within the Party; despite the limitations these are still in place, as the review below indicates. There continues to be a movement towards reform of judicial structure and processes during the period under review, 1987 - first quarter 1990, and an account of the impact on cadre accountability under law at the basic decentralized level is given below at some length.

Due to severe restrictions imposed by the availability of data and information the analysis in this paper is exploratory and the observations at the end are tentative.

\section{Cadre Discipline: Administrative Arrangements}

In the state administration, ministerial organisation exists since 1986 for supervising and disciplining cadres and orderly procedures are currently being established. The channels for the public's grievances against the cadres are being strengthened. There are, however, some limitations on the effectiveness and the reach of these arrangements below the xian level.

\section{State Administration}

Internal Investigation and Discipline. The Ministry of Supervision (jiancha bu), in the State Council, was reestablished in 1986; it was established in October 1950 and abolished in April 1954. ${ }^{5}$

At every local level, supervisory organs, corresponding to that at the State Council, are to be established by the local people's government with the concurrence of the immediately higher level supervisory organ. There is also a provision that the higher level 
supervisory organ, on its own initiative, can inspect the performance of the cadres in the administration at lower levels. These two provisions are expected to ensure that the supervisory work does not come under the sway of local vested interests. However the dichotomy in loyalties, to the appointing authority and to own higher organ, particularly when there is collusion between the officials at higher and local levels, can reduce the effectiveness of these provisions.

The reach of such supervision at the lowest decentralized level is limited. The lowest level of administration where supervisory organs are to be set up is the xian, though the state administration reaches down to xiang level. Also the functions of the supervisory organs are with respect to only state sector cadres.

The procedures for administrative inspection are being regularised with respect to, among others, the constitution of the inspection group, gradation of charges according to their gravity, handling of public complaints and of supporting evidence, punishment for false witness, recourse provisions for the cadres, gradations of administrative punishment, entry into the cadre's dossier and referral of cases to the Party discipline unit, to the legal department and to the procuratorate for appropriate further punishment. ${ }^{6}$

According to the Ministry of Supervision's work-report, the state inspection organs registered, during January-September 1989, 136,757 cases of violation of legal and administrative discipline by the state employees, investigated 36,233 cases (up by 168.88 percent over the corresponding period in 1988) and decided 30,018 cases (up by 130 percent). ${ }^{7}$ Administrative punishment was meted out to 21,315 persons (of whom 1,101 persons were above xian level); legal action was taken against 2,075 persons.

Currently the staff of the supervisory organs number 60,000 . However there are limitations on the effectiveness of the supervisory work, as underlined by the official work-report itself. At the provincial level, 53 percent of the state organs have not yet established supervisory organs with the requisite crosswise (hengxiang) links and the proportion is as high as 66 to 81 percent in cities and xian; even in economically advanced and densely populated areas, the supervisory work in xiang(zhen) is left to the few sent down from the xian level. The modalities by which higher 
level supervisory organs issue directions to their lower level organs, appointed by the lower level administration, are still to be formulated.

Adequate legal empowerment of the supervisory organs is still to be established, as for instance, for inspecting the bank accounts of the errant employees or temporary injunctions on the disposal of resources by them. There is the all too familiar hindrance from guanxi network and fear of investigating leading cadres; the workreport also cites instances of physical assault on the investigators.

Performance Auditing. Performance auditing by an autonomous organisation is an effective way of detecting cadres' irregularities. In the PRC such arrangements are a part of the state administration and the audit is only in financial terms. ${ }^{8}$ Also the society of auditors (shenji shiwu suo) is being established, with registration and licensing of auditors for spreading knowledge of auditing practices and for making such services available to economic entities, ${ }^{9}$ including those in the state sector. While the State Audit Bureau's functions cover the state administration, state enterprises, the central and specialised banks and financial trusts, and entities where state funding is involved, the auditing work at collective sector level is to be carried out by the members of the society under contracts.

Detailed specialised regulations on auditing work are currently being issued. ${ }^{10}$ It is reported that, in $1988,96,000$ units in the state sector were audited, of which 16,400 were basic units. The number of qualified auditors throughout the PRC is admittedly low, 40,000odd, of which 33,000 work in the state sector; this leaves little margin for auditing work at the collective sector level.

\section{People's Procuratorate: Complaint Reporting Centre (jubao zhongxin)}

Centres for receiving the public's complaints against cadres' decisions and actions, under the aegis of the People's Procuratorate, are increasing in number and in the work handled. Detailed regulation has been issued on their establishment and functioning: ${ }^{11}$ protection of anonymity and against reprisal, modes of communicating complaints, investigation of the evidence, advising on the civil and criminal liability for false evidence, forwarding the 
complaint to the Ministry of Supervision and to the Party Discipline Commission, time-limit for communicating the status of disposal, etc.

By the end of 1988 itself 2,784 complaint reporting centres have been set up by the Procuratorate offices reaching down to xian level as also 1,832 telephone 'hotline' booths. The public has not been slow to take advantage: $:^{12}$ in the first half of $1988,20,693$ complaints were received, 10,614 were investigated and 3,750 cadres were punished. Most of the complaints related to corruption.

Article 41 of the 1982 PRC Constitution provides for the public to present complaints directly to the judicial system and in the last five years 43 million such complaints had been received, of which 40 million were considered. Many of them were repeated complaints and the Supreme People's Court decided that letters involving its decisions previous to 1983 will not be reopened, thus finalising its work regarding complaints relating to the period of the Cultural Revolution. The Supreme People's Court had, in its 1988 workreport, publicly drawn attention to the prefunctory way in which such complaints were handled by the administration and the avoidable administrative delays, unlawful activities of the cadres during inquiry visits, intimidation of witnesses and their families and frivolous complaints lodged by people with no fixed address.

\section{Cadre Accountability under Law}

Currently, viewed from the limited perspective of decentralized economic development, progress towards cadre accountability under law continues, albeit slowly. Some important aspects of this process to be considered are the framing of appropriate laws, speedy and impartial judicial processes and the enlarging of the judicial structure to include the lowest territorial units; all, in the context of extension of the awareness of the rule of law, amongst the public and the cadres.

A legal framework for litigation on administrative decisions is emerging, with the enactment of 1989 Administrative Procedure Law, which is to come into effect in October 1990. The working of 
the judiciary and the state judicial organs is being slowly streamlined and regularised with a view to improved and well-ordered functioning. Beginnings are being made towards extending the reach of the law at lower levels, xian and below. Continuing developments, worthy of note, are some measure of self-criticism in the annual work-reports of the judiciary and judicial organs, ${ }^{13}$ critical contributions in the PRC law journals and exposure by the press of local abuses of power at provincial levels and below through reports and readers' letters to the editor.

\section{Party Cadres and the Law}

Both the 1982 PRC Constitution and the 1982 Constitution of the Chinese Communist Party stipulate that the Party is subject to law like any other entity. At the same time the leadership of the Party is supreme. The important way in which this seeming contradiction is to be resolved, as envisaged in Zhao Ziyang's report to the 13th Party Congress (hereafter: the 1987 Policy Statement), was that the Party's views (zhuzhang) become, through legal processes, state policy. Through Party organisations and Party members' model role, the Party would educate and guide the masses to implement the Party's line, main principles and policies, at the same time respecting the laws. Basic to such reforms is the separation of the Party from the administration.

The legal framework for ushering in the rule of law, holding the Party to account even on the lines envisaged in the 1987 Policy Statement, is slow to evolve, ${ }^{14}$ as indicated by some aspects:

Formally, the People's Congress, national and local, 'as the highest embodiment of the people's will', enacts laws. Local Congresses are authorised, only at provincial and similar levels, to enact legislation as required by local conditions and with regard to many of them it is unclear whether they are merely administrative regulations issued under national laws. The laws of the National People's Congress carry very few directives regarding their administrative implementation and the legal commentators in the PRC stress the need for such a list (liejuzhi).

The State Council is the executive arm which implements the laws through administrative regulations. The ministries and parastatal organisations also on their own issue administrative direc- 
tives. There is no standard nomenclature for them; according to one estimate there are no less than fifty to sixty terms. ${ }^{15}$ The accountability under law for such varying administrative directives is unclear. There is no practice in the PRC of the People's Congress, at national or other levels, of periodically reviewing the administrative actions taken under their laws.

The People's Courts, in adjudicating cases involving the administrative organs, do not consider whether the administrative acts conform with the objectives of the laws under which the acts are performed.

\section{Judicial System: Some Reforms}

Courts. Some of the imperfections in the working of the judiciary are being sought to be removed under recent in-house reforms by the People's Supreme Court, through internal supervision: in 1988 disciplinary action was taken against 333 staff members including 164 judges, with criminal proceedings against 16 staff members including 6 judges. ${ }^{16}$ To accelerate the trial of economic crimes, it has announced, along with the People's Supreme Procuratorate, time-limit and lenient consideration for voluntary confession and surrender. ${ }^{17}$ Public hearing of cases, with due notification to all concerned is being introduced, though admittedly some appeal courts are still to observe such practices. The respective competence of courts at various levels and due review processes are being streamlined. ${ }^{18}$

According to official estimate there are at present more than 130 laws and administrative decisions which have provided for litigation on administrative orders and 1,422 judicial tribunals have been set up for that purpose: 26 at the highcourt level, 242 at the middle level ( 63.5 percent of the total middle level courts) and 1,154 at the basic level ( 39 percent of the total courts at the basic level); also at the supreme court level there is one. In this as in other respects there is obviously an insufficiency at the basic level.

Currently there are 3,014 courts at the basic level (as compared to 431 cities, 248 xian under city administration, 647 areas under city administration and 1,936 xian) and 17,273 fading at town/township level (as compared to 56,002 towns and townships and 740,375 village councils). The administrative expenditure as on infrastruc- 
ture, salaries and housing is to be borne by the town and township administration and/or by voluntary self-raised funds; this is a constricting factor but some towns and townships report the establishment of additional fading. ${ }^{19}$ It is going to be a slow process.

As can be inferred from the annual work-reports of the People's Supreme Court, at lower levels of the judiciary the level of legal understanding has to be upgraded, the higher level courts have to provide more leadership to the lower levels, the living standards of the members of the judiciary needs to be improved and 'bureaucratism' prevails (i.e., refusal to register legal complaints and hear cases, law's delay, inadequate implementation of judicial decisions). For registration and speedy hearing of cases, and for guiding the basic courts and fading, increasingly judges from the middle level courts are being sent down or hold circuit sessions. ${ }^{20}$

People's Mediation Committees. There are currently throughout the country 1,002,635 People's Mediation Committees functioning under the Rural People's Committees and Urban Neighbourhood Committees: 749,021 in the rural area, under 88.7 percent of the Rural People's Committees; 88,339 in urban areas, under 92.5 percent of the Neighbourhood Committees; the rest are in industrial and commercial establishments.

The organisation and functioning of the mediation committees has recently been amended: ${ }^{21}$ along with clarifying the electoral procedure, the defraying of administrative expenses and the leadership in legal understanding to be provided by the legal assistants in the local administration, the 1989 regulation removes from their jurisdiction minor criminal offences, to be handled by the courts.

Two of the main features have been retained by the 1989 regulation. Submission of disputes is voluntary; either one of the parties can appeal to the basic-level court. The disputes covered are to be only those between citizens; excluded are disputes between administrative organs or between collectives or between a citizen and the collective or administrative organs. Instances of disputes covered by these committees at the rural level, as the author was informed during his field trip, are those relating to family maintenance, marital life, land rights or property inheritance, neighbourhood quarrels and robbery. 
As elective bodies the mediation committees are not part of the administration. Nor are they judicial organs. The references to them here are to indicate the sieve by which the burden on the lower courts is lightened; during 1981-1988, as an yearly average, 7.2 million disputes are reported to have been mediated. Also the provision for legal guidance to be given to the committees has an educative fall-out in terms of rural awareness of the legal system and its functioning. Currently there are 43,618 legal assistants in the administration and nearly half of them are engaged in educating and training the members of these committees. The 1989 workreport of the People's Supreme Court mentions that the lower courts 'guided' (zhidao) the committees in 3 million cases.

State Judicial Organ. The Supreme People's Procuratorate is by all accounts an increasingly effective body: of the 1.4 million cases handled by the People's Courts in 1988, nearly a quarter were brought to court by the Public Procuratorate offices. It has publicly reported for the first time the results of investigation of its own officials: in 1988 administrative and Party disciplinary action was taken against 340 officials; 9 were dismissed, 22 lost their Party membership and criminal prosecution was undertaken against 60 . It is clarifying its powers through a series of regulations, as on forensic medicine, voluntary confession and surrender in cases of corruption, on taking cognizance of cases of infringement of rights of the citizens, etc.

The People's Procuratorate is empowered, under the 1982 Civil Procedure Law (Trial Implementation), article 12, to exercise supervision and control (jiandu) over the People's Courts. Currently there is no specific enactment laying down the specifics. ${ }^{22}$ The approach is ad hoc, with joint issue of regulations with the People's Supreme Court, the Party Central Disciplinary Commission, the Ministry of Public Security, etc.

The People's Procuratorate offices number 3,495. Apart from the Supreme People's Procuratorate, there are 31 at provincial level and 367 in cities; basic level offices, in the xian, are only 2,979; below the xian level there are only 117 branch offices (paichu jiegou). The reports of the People's Supreme Procuratorate themselves stress the inadequacy in staff, number of offices and knowledge of law, the 
lack of adequate communication and referral between lower and higher level offices and the unwillingness to investigate senior local officials. In the first three quarters of 1989, in 100 xian the Procuratorate offices did not file even a single corruption charge and in more than 700 xian there was not even one confession and voluntary surrender by corrupt official. ${ }^{23}$

\section{Some Statistics}

Statistics pertaining to judicial adjudications and economic and other crimes have well-known limitations. Arguably they are a shade better than anecdotal evidence, particularly when, as in the PRC's relevant work-reports, released in the latter half of 1989 and afterwards, there are official admissions which are indicative. ${ }^{24}$

The work-reports covering 1986, 1987 and 1988 indicate a significantly increasing number of cases, civil and criminal, before the judiciary and a growing proportion of them brought to court by the People's Procuratorate. Over the five year period since 1983 the People's Procuratorate brought to court 21,700 cases of violation of legal discipline by the cadres (faji) involving inquisition by torture and extortion of confession, unlawful detention and imprisonment, illegal and irresponsible search and negligently causing accidents.

The rapid rate of increase in economic crimes is vividly brought out in the annual work-reports of the Supreme People's Court. In the state organs and in industrial and commercial establishments the proportion of leading cadres responsible for economic crimes reached 10 to 15 percent and among cadres, 22 to 28 percent. The reports specifically underline the inadequate investigation and prosecution of state organs and commercial enterprises involved in serious crimes.

Economic disputes accounted for a significant part of the civil cases handled by the People's Courts: in 1988, 36 percent. Most of the economic disputes centered on economic contracts: in 1988, 91 percent. Disputes with administration, regarding production responsibility contracts in agriculture which increased significantly during 1984-1986, have been decreasing due, according to the 1988 report, to local courts working with the administration in better understanding and implementation of the contract system and improved enforcement of the notarisation provisions. 
The number of cases before the courts involving administration adjudicated by the courts is meagre, as indicated by the sparse statistics available for the years 1987 and 1988: 14,513 cases registered (more than half relating to administrative decisions regarding public security and land administration) and 13,248 adjudicated. In nearly 50 percent of the cases, the administrative decisions were upheld; in 9.8 percent, overturned; in 5 percent, amended; 25 percent of the cases were dismissed. Relevant in this connection is the observation in the work-report that in court decisions involving administration the lack of enforcement increased from nearly 20 percent to nearly 30 percent due not only to inefficiency on the administration's part but also to obstruction by regional and local administrative units with 'local patriotism' or vested interests.

\section{Administrative Law (Litigation Procedure)}

The PRC has deferred the promulgation of a Civil Code, with special parts as on administrative law, adopting in its place, the 1986 General Principles of Civil Law. The 1982 Civil Procedure Law (Trial Implementation) laid down general procedures for civil litigation. In the light of experience gained so far, this 1989 Law has been adopted. ${ }^{25}$ It is to come into effect on October 1, 1990, the forty-first anniversary of the founding of the Republic.

Some of the important provisions of the 1989 Law, of relevance to the theme of this paper, are noted below:

The law (article 11) lists the administrative acts which are within its scope: for instance, not only the exceeding of the legally stipulated administrative autonomy, infringement of personal and property rights and administrative penalties but also rejection of or failure to respond to legally valid applications for the issue of permits and licenses and for the protection of personal and property rights. The law stipulates a limitation period of three months, beginning with the date on which the specific administrative act complained against is known.

The law specifies (article 12) various administrative acts excluded from its scope: for instance 'acts of state' (guojia xingwei), 'generally binding decisions or orders' (pubian yueshulide jueding, mingling), 
provisions which can be construed in various ways.

Under the law citizens, legal persons or other organizations can be plaintiffs. The administrative authorities that performed the specific acts shall be defendants; in reconsidered cases, when appeals have been made to higher administrative authorities, the People's Court will be the final authority. The jurisdiction of the courts at various levels is also laid down.

Cases are to be registered within seven days of written complaint; when not accepted for hearing the plaintiff can appeal (article 42). In setting forth the procedures and time limit for hearings, the law lays down (article 57) a period of three months from the commencement of proceedings for the first instance decision, subject to possible extension to be approved by the higher level people's court.

The judgements rendered by the court can include revoking all or part of the administrative action (article 54), compelling the performance of a specific administrative action within a prescribed period (article 54), fixing the liability for compensation (article 67) and, in case of acts deemed criminal, 'transferring the relevant materials' to the public security or procuratorial authority (article 56). The law specifically excludes mediation by the court in hearing administrative cases (article 50) except in compensation proceedings (article 67).

The 1989 Law clarifies many aspects on civil litigation regarding administrative decisions which were not covered by the 1982 Civil Procedure Law. The framers of the law stress that litigation on administrative decisions is a comparatively new concept in the PRC. They envisage that the People's Courts will be flexible, go by the intentions of administrative decisions and in their judgements enable the administration to carry out its legitimate functions. Ambiguities still remain which await for their resolution the experience with the working of this law: to start with, the near universal lack of clarity or appropriate details in the empowerment of administration for implementing a law. An aspect which has not received adequate attention of scholars of contemporary China is the continuing free and lively debate in the PRC law journals on various unclear aspects of this law. ${ }^{26}$

The 1989 Law is a significant bloc in the slowly emerging legal edifice in the PRC. As an earnest of its implementation the State 
Council has called upon all levels of administration to study the 1989 Law and to ensure the conformity of the existing and future administrative regulations, and their execution, with the 1989 Law. $^{27}$ Regulation on the infringement of personal rights has also been issued in the beginning of 1990, detailing the conditions under which the People's Procuratorate will directly handle cases in line with the Criminal Law and the Law on Criminal Procedure. ${ }^{28}$

\section{Legal Practices}

A notable feature of the judicial process in the PRC is the reliance on mediation at every stage and the prior consideration given to mediation before judicial adjudication. In the case of disputes over administration's decisions the courts actively encourage the plaintiffs to appeal to the higher levels of administration.

There is no system of case law. Even in the sparse reports available on court decisions the legal basis for the decisions is generally not given. Compilations of court decisions are made and circulate among the judicial organs as internal documents but they are largely for information. A recent development is the regular publication of some important decisions of the Supreme People's Court. $^{29}$

Overshadowing the judicial niceties is the fact that the members of the judiciary, though nominally elected by the correspondinglevel People's Congresses, form part of the nomenklatura system. The lawyers in the PRC are appointees of the state; while protecting the interests of the clients they are at the time expected to uphold 'socialist law', mediate between the administration and the client and can at any stage withdraw from the case.

\section{Cadre Self-Appraisal and Discipline}

Self-regulatory mechanisms, vital in the case of the supreme leadership of the Party, are formally provided for. The importance of the cadres' self-criticism sessions is continuously stressed as also the need for their improved functioning. In spite of the strengthening of the Party discipline inspection apparatus internal Party 
discipline is admittedly slack.

\section{Self-Criticism}

Criticism and self-criticism by the cadres (piping he ziwo piping) is called for by the Party Constitution. The institutional setting for it is the meeting for democratic activities (minzhu shenghuo hui) which the Party committees, at every level, are expected to convene on a regular basis. In short, in such meetings it is intended that the Party's policies and programmes are to be explained in detail and the cadres' activities are to be mutually appraised by them on the basis of equality and free expression: 'say all you know, say it without reserve'(zhi wu bu yan, yan wu bu jin); 'blame not the speaker but be warned by his words' (yanzhe wu zui, wenzhe $z u$ jie). ${ }^{30}$

The proceedings of the self-criticism sessions are recorded but they are not to enter into anybody's dossier. There are formal provisions, as in the 1987 Policy Statement, under which Party disciplinary action is to be taken against any leading cadre or organisation in case the cadres' rights (to criticise the superiors) are infringed or retaliatory action is taken. Slander and libel and false charges are to be firmly discouraged and the cadres are to be warned of the legal provisions against such activities, as in the PRC Constitution, section 38 and in the PRC Criminal Law, section 138. From the highest level (Deng Xiaoping), research on strengthening the system is called for but within limits (fencun shidang), disallowing joint, factional attacks on anybody (buyao gao weigong) as well as joint campaigns (gao yundong).

Dissatisfaction with the actual working of the system - along with the recognition of its importance - can be gleaned from the publications in the PRC: ${ }^{31}$ a sample survey of 200 Party branches in 1988 indicated that in many of them even once a year self-criticism sessions were not held and 70 percent of the cadres felt that it was not possible to speak out frankly and sincerely (kaicheng bugong); also, when such meetings are held they are often of ancillary nature to day to day work rather than self-criticism sessions.

Among the basic requirements for the succesful functioning of this system, as perceived in the large volume of critical commentaries in the PRC, are the participation of the general public in the cadre self-appraisal sessions and the strengthening of democracy 
inside the Party (dangnei minzhu).

Public participation, discussed below, could enhance cadres' responsiveness to the public and also provide some check on arbitrary retaliatory actions (qiuhou suanzhang) by the leading cadres.

Democratic practices within the Party can encourage the cadres' criticism and self-criticism if they feel confident that the officebearers are democratically elected and responsive to them. Formal provisions exist in the Party's directives for such practices but the critical commentaries in the PRC indicate that they are not being implemented. ${ }^{32}$

Democratic election to the Party branch committee, according to a manual of procedures at the xian level, requires secret ballotting, the number of candidates exceeding the number of posts by a minimum of 20 percent and plurality of half or more than half of votes cast. ${ }^{33}$ The list of candidates is to be forwarded to higher level Party committee for information, not necessarily for approval. Admittedly the plenary session of the Party branch, to which the Party committe is accountable for Party activities as well as for electoral arrangements, is in many instances not convened regularly as stipulated and consultations with higher level Party committees in practice lead to the appointment of officials by them. Dissatisfaction of the cadres has also been voiced at the lack of transparency in discussions at higher level Party decision-making and the inadequacies and delay in making available relevant Party documents to lower-level cadres.

\section{Internal Party Discipline}

Under the Party Constitution five kinds of disciplinary action against the Party members are provided for. ${ }^{34}$ They are in ascending order of severity:

- admonition

- severe admonition

- removal from the job or transfer to a lower post

- placing the cadre under probation within the Party

- surveillance for a year or for a maximum of two years along with suspension of Party membership rights

- cancellation of Party membership. 
Infractions of Party discipline are broadly grouped into two categories, minor and serious, without any indication of the correspondance with the five kinds of disciplinary measures.

The cadre's offence is considered minor when there is a willingness to examine and correct the mistake by oneself; when involved in group-wise breaches, he performs a meritorious service by speedily exposing and denouncing them; when it is due to his subordinate status; when he is coerced or inveigled into participation.

Serious offences are considered to have been committed when the cadre is the leader of collective infringement; when after repeated disciplinary measures there is no repentance; when the results are serious; when there is a concealment of mistakes and the buck is passed on to others; when there is a refusal and defiance of Party inspection and there is an assault on and retaliation against Party inspectors or informers; when serious offences are committed like violation of law, forcible restraint of persons, graft and malappropriation of Party funds, of funds and materials earmarked for flood control and other emergencies, of family pensions for the disabled and deceased, general relief etc.

All disciplinary action has to be put to vote in the general meeting of the Party branch and has to be approved by more than half the votes. The Party member has the right to defend himself or appeal against the decision to the higher level Party committee; in practice such appeal seldom, if at all, reaches beyond the xian level Party committee.

Disciplinary action against a Party cadre in the administration is to be jointly undertaken by the Party disciplinary unit and the legal or inspection organ in the administration, under the leadership of the Party Committee; ${ }^{35}$ the main responsibility for disciplinary action is to depend on whether the Party or the administrative discipline has been violated. In the case of criminal charges against the cadre the Party cannot substitute its disciplinary action for criminal procedures but has to hand over the case to the People's Procuratorate with all the required documentation.

Party cadres in the administration are subject to both Party and administrative disciplinary action. For instance where the cadre has been removed from his position within the Party or is under proba- 
tionary surveillance or has forfeited his Party membership, the cadre automatically loses his position in the administration. Where the cadre has been removed from his job in the administration he loses his Party membership.

The laxity in the Party discipline and the need for strengthening it has attracted frequent comments in the PRC. ${ }^{36}$ Recently some measures have been taken to enforce Party discipline. Regulations have been issued towards the end of 1989 announcing strict disciplinary measures against Party members who violate 'socialist moral ethics' ${ }^{37}$ The tasks entrusted under the Party Constitution to the basic Party units are being slowly translated into specific performance targets for the cadre. ${ }^{38}$ The dossier work is to be upgraded in terms of facilities and funding. ${ }^{39}$ The issues in improved collection and management of Party membership fees, in selfreliance of the Party in funding its activities and in the separation of Party funds from administration funds are being actively discussed. ${ }^{40}$

The Party's disciplinary organs have been strengthened in staff, with a heightening of its status. At the highest Party level the Central Discipline Inspection Commission was in 1984 included in the Central Committee's nomenklatura even while there was a general devolution of its nomenklatura authority to lower provincial levels. ${ }^{41}$ For the Disciplinary Commission to perform efficiently its functions, the 1987 Policy Statement laid down that they should not deal with infractions of law or of administrative regulations but should concentrate on fostering Party spirit and enforcing Party discipline. The staff of the discipline inspection organs is currently as high as 200,000 , a high proportion of 3 to a 100 state cadres. ${ }^{42}$

In practice, the disciplinary process gets relaxed if the cadre shows an awareness of his wrongdoing and is willing to correct himself, thus enjoying lenient treatment. In fact, the policy of 'education if the mistake is small, punishment only if the mistake is grave' is, according to commentators in the PRC, weak as there is no clear correspondance between the infraction and the types of disciplinary action. Also, at the decentralized level, the Disciplinary Inspection Committee, though nominally under the supervision of both its higher level committee and the Party branch committee, is appointed by the Party branch committee; its willingness and ability 
to inspect and discipline the Party branch committee members are thus inhibited.

The weak impact of the diciplinary measures can be gauged to some extent by the fragmentary statistics available. ${ }^{43}$ In the seven years, 1982 to 1988 , the Central Disciplinary Commission meted out disciplinary punishment to 879,167 Party members; of them 193,373 forfeited their Party membership. At the xian level the number expelled from the Party during that period was only 36,494 . According to a press report, in the two years September 1987 to $1989,60,000$ were persuaded to retire or were expelled from the Party by public democratic appraisal.

\section{Cadres Responsiveness to Public}

Two forms, characteristic of the PRC, under which the public reacts to bureaucracy, continue to be operational: public evaluation of cadres' performance and the 'letter and visit' system. The parameters under which legislative supervision over elected officials is exercised are still in the process of evolution.

\section{Yushui Guanxi}

The slogan from the Liberation days, the relationship of the Party to the public is that of fish to water, (dang he qunzhong de yushui guanxi), is still in effect. Cadres' responsiveness to the public is sought to be ensured through public participation in the evaluation of cadre performance and the 'letter and visit' system. They are viewed as a useful supplement to the administration's complaint receiving centres.

In public meetings organised by the local government or Party unit the public is invited to criticise, evaluate, recommend for promotion or demotion or dismissal and to nominate for appointment leading management cadres. Secret ballotting is utilised.

According to preliminary statistics released by the central secretariat of the Party, in the Fujian, Guangdong and Gansu provinces 130,000 cadres were subjected to public evaluation; ${ }^{44}$ in Hebei province 95 percent of the cadres at the township and xian 
levels underwent performance evaluation by the public; and in the whole country, of the cadres at those two levels, 16 percent was commended, 76 percent was found adequate and 8 percent inadequate. Though some scope is thus provided for public ventilation of views on the working of the administration such performance evaluation, with its broad categorisations, can hardly be deemed scientific or reliable.

The recent drive against corruption has revived this system and various reports in the provincial press indicate that such public meetings are being utilised for exposing petty corruption by the cadres, harnessing the underemployed cadres for invigilating the performance of their colleagues and even formally setting standards of behaviour for the cadres. ${ }^{45}$

'Visit and public letter work' (xinfang gongzuo) has been emphasized at the highest policy level. ${ }^{46}$ Under this system the cadres are expected to be in constant touch with the public, attuned to its views and attending to its needs. ${ }^{47}$ During the contacts and settlement of complaints the cadres are to educate the public on Party principles and policies. A cadre is assigned a number of households to be contacted, generally between 1 and 5; the household contact system is also implemented through small Party groups. ${ }^{48}$ One of the main functions of the contact system is to conduct enquiries and settle complaints voiced through public letters. According to the work-report of the Ministry of Supervision, in the first eight months of 1989, there were 213,271 complaints against cadres which were received under the letter and visit system.

At the basic level, it is the xian level Party committee and the administration which jointly set up an office for public complaints and official visits of enquiry. Except when high level policy issues are involved, issues arising at xian level and below are to be settled by the xian office, working through the basic Party units below. To make the system effective the cadre's dossier is to carry details of his xinfang work, as also public commendation or criticism. ${ }^{49}$

\section{Legislative Supervision}

Local People's Congress. The work of the political functionaries is subject to supervision by the Local People's Congress which elects 
the head and deputy head of the administration in its area and, at the level of xian and above, the head and deputy head of the judicial organs. ${ }^{50}$ It is empowered to plan the administration's work, in the light of national development plan and policies, and to scrutinise and approve the budget. It can set aside any inappropriate local administrative decision and can remove from office the officials it has elected. It should be noted that any inappropriate regulation and decision of a lower level Local People's Congress can be set aside by the next higher level Local People's Congress: for instance, those of xiang Congress, by xian Congress; so far, as the author was informed, such setting aside of decisions has been when local regulations were not in line with national laws or when they were not properly drafted.

The Local People's Congress exercises legislative power and inspection and supervisory power (jiandu quan) as the highest embodiment of the people's will in its area, the legal commentators repeatedly emphasize but such a preeminent role is still to evolve effectively. The Congress has a dual role (yifu liangyuan): legal supervision (falü jiandu) and work supervision (gongzuo jiandu).

Overall there are two factors conditioning the work of the Local People's Congress: the nomenklatura system under which the political officials are 'elected' and the electoral system which determines the composition of the Congress. Both these factors are undergoing some degree of democratisation, but within the parameters fixed by the Party. In recommending the candidates for leading administrative positions the local Party committes gauge the preferences of the Congress members, as indicated in the first part of this paper. While the predominance of the Party in the Congress is left unaffected, some democratic elements have been introduced in the electoral process which, under the 1986 Law, is based on direct election upto xian level Congress, multiple candidacy, secret ballotting and the winning of half or more the votes cast.

Various instances have been reported in the PRC press of the multiplicity of candidates, even seven-fold, for the seats in the Local Congresses. The preparation of the final slate of candidates is left to the Electoral Commission whose establishment and functional modalities are left to the Standing Committee of the Local People's Congress under the 1986 Law; the law enjoins the commission to 
consult the electorate and respect the majority view. In practice the Electoral Commission is convened by the Party branch and in its working the Party secretary and the chairman of the Standing Committee of the Local Congress participate.

Various practices are also reported with regard to the finalisation of the list of candidates: ${ }^{51}$ an agreed, fixed proportion to be nominated by the Party; the Party scrutinising and approving the slate of candidates all of whom are those recommended by the people, as laid down in the 1986 Law; the simultaneous presentation to the electorate of all the lists, as prepared by the Party, by the collective groups and jointly by more than ten voters; special reservations for women, minority nationalities, non-Party personages etc. Scattered reports are available on how these practices have worked out: according to incomplete statistics on the direct elections to xian and cun congresses in 29 provinces, autonomous regions and cities by the end of 1987 , more than 70 percent of the elected members were those recommended jointly by more than ten voters. Some instances are also reported of Party nominees not making it to the final list of candidates.

In the carrying out of work-supervision duties emphasis is being placed on the members of the Congress interpellating the administrative officials on their work and the members keeping in touch with the constituents through visits and by mail. Basic to an improvement of the system is the enhancement of the legislative capacity of the members: towards this end beginnings have been made with the establishment of research offices and select committees. As interpellation of administration is a comparatively new phenomenon in the PRC a few provinces have compiled a manual for such procedures.

All People's Congresses have to present annual reports on their work to the general public. Generally such reports are carried by the press only in provincial capitals on the Provincial People's Congress. At lower levels they are available only to the members of the Congress. An oft-repeated complaint is the nature of workreports of the administration and of the Congresses: they are a mere formality; they are not issue-oriented but descriptive; they are too much concerned with minutiae and are not selective with respect to main issues; once the higher level Congress or administration issues 
a work-report the lower organs are left with only the implementation of the findings.

The supervision and disciplining (including removal from office) by the Congress of the leading officials elected by it has, in practice, raised some controversy. Legislative supervision of the work of the administration without interfering with routine administrative decisions, at best a complex operation, is being repeatedly urged, as for instance, by a country-wide review of the People's Congress at the provincial level held in Shandong in October in 1987; an important decision in this respect is that members of the Standing Committee of the People's Congresses will not simultaneously hold jobs in the administration. ${ }^{52}$

In addition to the oversight by the Congress the leading cadres in the administration are subject to supervision and discipline by internal administrative organs, by the Party disciplinary organs and public evaluation by the masses. What continues to be an issue is whether the Congress, in this respect, is primus inter pares or is the final arbiter. What is envisaged in the PRC is that Congress will dismiss the wrong-doing official after appropriate enquiry and civil and criminal proceedings will be undertaken only by the concerned judicial authorities; when the official is a Party member, he is to be subject to both Congress and Party action.

Village People's Committees. Experience with the operation of the law establishing them is, as outlined in the first part, still limited and the committees continue to operate (mid-1989) as the former production brigades did. ${ }^{53}$ However some formal provisions of the 1987 Law deserve to be noted.

In addition to civil administration, public security, implementation of public services and public welfare programmes and mediation in civil disputes, the Committee is to be responsible for local implementation of national laws, policies and decisions; manage collectively-owned land and property like implementation of grain purchase contracts, farmland construction projects, environmental protection etc; encourage and promote cooperative groups for economic activities while respecting their right to selfmanagement. For such management purposes the Committee is empowered to raise financial resources from within the village, 
subject to the approval of the Village Council. The main groups under the Committee are People's Mediation Committee, the Public Security Committee and Public Health Committee, which are also elected by the Village People's Council.

The Village People's Committee is to be directly elected by and is to report to the Village Council, comprising all the villagers above 18 years of age or representative from each household in the village. The self-governing right of the Committee is sought to be ensured by a specific provision regarding the relationship with the administration at the higher xiang level and above: the relationship is not to be hierarchical, with the Committee subordinate to the higher level administration, but of mutual cooperation, with the higher level administration providing leadership at policy level on national policies and decisions.

The separation of the Party from the Committee is to some extent provided for by the requirement that the Committee members have to be directly elected by the Village Council, with the Party members also submitting to the electoral process. To obviate the influence on the autonomy in decision-making by the Committee, barred from being members of the Committee are officials of collective enterprises at xian and xiang levels which can send nonparticipating observers; officials of collective enterprises at the village level may be allowed to be elected to the Committee in view of their local concerns.

\section{Some Tentative Observations}

The supreme leadership of the Party at the basic level is an ineluctable fact of rural life in the PRC. Various general explanations are in vogue, for the respect for authority and group cohesiveness, in terms of 'Confucian spirit', with many variants of the term ${ }^{54}$ or of 'Chineseness' drawn from studies of the ineffable 'national character ${ }^{55}$ presumably syncretising Confucianism with Leninism or of systematically induced dependence on authority. ${ }^{56}$ Given its short confines this paper does not enter into this class of issues; it proceeds on the basis of the continuance of the leadership of the 
Party, whatever be the view from outside the PRC.

Many insightful studies are currently available bearing on the main theme in this paper which alludes to the findings of these studies in brief general terms. ${ }^{57}$ The studies are historical, covering the recent past; many of them rely, and justify such reliance, on interviews with mainland refugees in Hongkong. ${ }^{58}$ In contrast this note ventures into the area of contemporary developments; also it relies on data and information collected in the PRC and on critical commentaries published in the PRC itself.

The state reach into society, through the Party cadre system, is viewed in this paper at two levels one of which is the divorce of the Party from administration, i.e. reform of the nomenklatura system. The indirect economic levers of planning, like credit, fiscal and monetary policies, are intended to operate even at the most decentralized level but in an impersonal automatic way; for instance, rationalization and modernization of banking practices in the light of overall credit policies should not be construed as state impositions. Such indirect economic instruments are not to be viewed as state penetration. However, here, too, the nomenklatura system can operate offsetting the optimal operation of such indirect planning instruments. On this comparatively neglected but vital aspect the information presented in this paper suggests that beginnings were made in 1989 and some limited progress had been achieved in separating the Party from administration, a process which might have been arrested in 1990. More studies are needed.

On the 'local space' left by the state in its reach into society the well-known historical approaches to a study are the 'clientilism' between local cadres and their favoured local groups and conflicts between local factions and their higher authorities. More evidence than is usually presented is needed to indicate whether the overall state policies have been subverted thereby or whether there had been an adaptation of state policies to local conditions without a serious violation of state policies or whether such adaptation is specifically allowed for by national policies. The maneuverability of the local cadres would depend on their collusion with their immediately higher authorities against the state. A crucial determinant, not being studied adequately due to non-availability of information, is the relationship of higher units of the Party to its 
lower units. Albeit limited information, it is suggested in this paper, for further consideration, that the Party units at the xian level have a great degree of latitude in all aspects of Party activities.

Given the 'local space' the provisions for evaluation of cadre performance and enforcement of discipline are analysed in this paper with more emphasis given than is customary in current literature to internal administrative provisions, to the working of the Local People's Congress and to the arrangements being made for reforms of the judicial system particularly with regard to its reach towards lower levels. In developing countries with a shortage economy the abuse of power by local officials in the allocation of crucial materials is a well-known common feature, not peculiarly characteristic of the PRC. Unless one is averse to planning with its varying degree of control over the allocation of scarce materials to priority areas and hence seeks an untrammelled working of free market forces, even without "dual pricing," one attempts to control the inevitable errant behaviour through administrative discipline, provisions for public complaints, debate in public forums and provisions for recourse to the judiciary; within the parameters as fixed by the Party, progress is being made with respect to all these aspects. The list of legal provisions in the PRC with respect to bribery and corruption carrying penalties is too long to be included in this paper. Militating against the dismissal of them as mere paper provisions are the self-criticism to be found in official reports, the free and lively debate not only in learned law journals but also in letters to the editor in the press and educative campaigns for awareness of law.

Thiagarajan Manoharan is a Senior Research Associate at the Center for East and Southeast Asian Studies, University of Copenhagen

\section{NOTES}

1 The first part appeared in Copenhagen Papers in East and Southeast Asian Studies, No. 5, 1990, pp. 113-136; it is referred to in this the second concluding part as Part 1. The period covered in the two parts is from the third quarter of 1987 to the first quarter of 1990.

2 The latest comparable figures from an official source are 8.85 millions at 
the end of 1989 and 8.42 million at the end of 1988. See Zhongguo tongji zhaiyao 1990 (A statistical survey of China 1990) (Beijing: Zhongguo tongji chubanshe, 1990); the figures are not disaggregated in terms of state and collective sectors. According to Chen Lianchang, DeputyMinister, Ministry of Personnel, the professional civil servants (gongwuyuan) in the administrative departments number only 4.2 million, of which half-a-million is accounted for by the State Council. See Chen Lianchang, "Woguo gongwuyuan zhidu jiben kuangjia chubu xingcheng" (The basic frame of professional civil service in our country is taking shape), Fazhi Ribao, November 11, $1989, \mathrm{p} .1$. On the cadre strength and emoluments at the collective sector level, important with respect to the burden of the cadres on peasant life in contemporary China, one searches in vain for reliable overall figures.

3 For the salary structure at the state level, see Laodong renshibu xingzhengguanli kexue yanjiusuo zuzhi bianxie, Guojia gongwuyuan zhidu jianghua (National civil service system explained) (Beijing: Laodong renshi chubanshe, 1988), chapter 14; see Part 1 , note $25, \mathrm{p}$ 135. The figures do not cover official perks; the aggregate, item-wise, figures on subsidies given are not classified by salary grades.

4 See Guojia kewei Zhongguo keji cujin fazhan yanjiu zhongxin 'zhengzhi tizhi gaige shehui jichu yanjiu' ketizu, "Guanyu zhengzhi tizhi gaige shehui yulunde chubu yanjiu" (Preliminary research on society's public opinion on the reform of the political system), Zhongguo Wenhuabao, October 2, 1988, p. 3; Ge Yaoliang, "Guanyu wo guo shimin zhengzhi gaige yishi he xintai de fenxi" (An analysis of the awareness and fee- lings of our country's city people towards political reform), Juece yu Xinxi, No. 1, 1989, pp 36-40.

5 "Guanyu sheli zhonghua renmin gongheguo jiandubu de jueding" (Decision on the establishment of the PRC Ministry of Supervision) (December 2, 1986); "Guanyu zai xianyishang geji renmin zhengfu sheli xingzheng jiandu jiguan de tongzhi" (Announcement on the establishment of supervisory organs by people's government at every xian level and above) (August 7, 1987). For details of its internal structure see Zhongguo xinwen fazhan gongsi, ed., Zhongguo zhengfu jigou minglu (List of the PRC government organs) (Beijing: Xinhua chubanshe, 1989), Vol. 1, pp. 50-59. Also, Luo Yazhong, Luo Jianping and Wong Yuan, Xingzheng jiandu he jiandu xingzheng (Administrative supervision and supervision of administration) (Chengdu: Sichuan renmin chubanshe, 1989), pp. 29-49.

6 See, for instance, "Zhongguo Renmin Gongheguo jiancha jiguan diaocha chuli zhengji anjian shixing banfa" (Inspecting and handling on a trial basis by the PRC supervisory organs of cases concerning administrative discipline), (May 11, 1988); "Guojia xingzheng jiguan gongzuo renyuan tanwu huilu xingzheng chufen zanxing guiding" (Provisional decision on administrative punishment of employees of state organs for corruption and bribery), (September 13), 1988; "Guojia xingzheng jiguan gongzuo renyuan tanwu huilu xingzheng chufen zanxing guiding shishi xize" (Detailed rules for implementation of State Council provisional decision on administrative punishment of employees of state organs for corruption and bribery) (8 September 1989).

7 "Guanyu jiancha jiguan jinnian yilai kaizhan fan fubai douzheng de qing- 
kuang jixia yibu gongzuo de huibao" (Work-report on launching the anticorruption fight reaching downwards from this year on) (Delivered by Wei Jianxing, Minister of Supervision, to the tenth session of the Standing Committee of the Seventh National People's Congress, October 25,1988 ).

8 "Zhonghua Renmin Gongheguo shenji tiaoli" (The PRC audit regulation) (Announced by the State Council on November 30, 1988); "Zhongghua Renmin Gongheguo shenji tiaoli shixing xize" (Detailed rules and regulations for implementation of the PRC audit regulations) (Announced by the PRC Audit Bureau, June 21, 1989). For government accounting practices and arrangements, see "Zhonghua Renmin Gongheguo kuaiji fa" (The PRC accounting law) (Approved by the seventh session of the Standing Committee of the Sixth National People's Congress, February 1, 1985).

9 "Shenjishu guanyu shehui shenji gongzuo de guiding" (The State Audit Bureau's decision on social auditing work) (Announced by the State Audit Bureau on July 5, 1989).

10 For instance see, "Shenjishu guanyu neibu shenji gongzuo de guiding" (The State Audit Bureau's decision on internal audit work) (Announced by the State Audit Bureau on December 2, 1989); "Xingzheng danwei dingqi shenji zhidu" (Periodical audit system for administrative units) (Announced by the State Audit Bureau on December 14, 1989).

11 "Renmin jiancha yuan jubao gongzuo ruogan guiding (shixing)" (Some decisions for trial implementation on the work of the People's Procuratorate relating to reporting of complaints) (Approved by the Supreme People's Procuratorate on November 25, 1988).
12 For a detailed discussion of specific instances see Jin Mei, Yi Hu, "Jubao beihou de yinying" (Background to public complaints), Falü yu shenghuo, No. 3, 1990, pp. 2-6.

13 In fact, the critical comments and statistics in this section are based on the recent annual work-reports of the People's Supreme Court and the People's Supreme Procuratorate presented by their incumbent heads to the sessions of the National People's Congress: Zhang Tianxing, "Zuigao renmin fayuan gongzuo baogao" (Work-report of the People's Supreme Court) (April 6, 1987, April 1, 1988); Yang Yizhan, "Zuigao renmin jianchayuan gongzuo baogao" (Work-report of the People's Supreme Procuratorate) (April 6, 1987, April 1, 1988). Also see Zhongguo falü nianjian 1989 (China law yearbook 1989) (Beijing: Falü chubanshe, 1990) pp. 1081-1085.

14 For the perceptions in the PRC as reflected in the large volume of contributions in the PRC law journals, see, for instance, the following: Zhang Shangzhuo, "Guanyu xingzhengfa gainiande yixie wenti" (Some conceptual issues in administrative law), Falü Xuexi yu Yanjiu, No. 1, 1988, pp. 8-13; Hu Jiansen, "Falü xingzheng qiangzhi zhixing" (Strengthen knowledge and application of law in administration), Faxue Yanjiu, No. 1, 1988, pp. 25-31; Sun Wanzhong, "Zai shenhua gaige zhong jinyibu jiaqiang zhengfazhi gongzuo" (While deepening reforms gradually strengthen administrative and legal work), Shanghai Fayuan, No. 4, 1988, pp. 3-4; Chen Zizhong, "Xingzheng jiguande falü diwei yu xingzheng faren zhidu" (The legal status of administrative organs and administrative system as legal person), Faxue, No. 4, 1988, pp. 8-10; Zhang Shuyi, "Woguo xingzheng 
susong zhidu chuyi" (My humble opinion on our country's administrative litigation system), Zhengzhixue Yanjiu, No. 4, 1987, pp. 34-36.

15 For instance tiaoli, banfa, jueding, jueyi, zhiling, zhishi, tonggao, bugao, fangan, zuzhi tongze, zuzhi jianze, zuzhi guicheng, shishi gangyao, shishi xize, shishi fangfa.

16 "Quanguo geji fayuan jiang jianli jiancha jiguan" (Courts at every level throughout the country to establish investigation organ) Fazhi Ribao, May 11, 1989, p. 1.

17 "Zuigao renmin fayuan, zuigao renmin jianchayuan guanyu tanwu, shouhui, toujidaobao deng fanzui fenzi bixu zai xianqinei zishou tanbai de tonggao" (The People's Supreme Court, the People's Supreme Procuratorate announcement on voluntary surrender and confession within a fixed period by offenders involved in corruption, bribery, speculation, profiteering etc.) (August 15, 1989). The announcement is effective with respect to all, in the state, collective and individual sectors.

18 "Zuigao renmin fayuan guanyu geji renmin fayuan chuli minshi he jingji jiufen anjian shensu de zanxing guiding (Preliminary decision of the People's Supreme Court concerning the handling of appeal cases at different levels of people's courts involving civil and economic disputes) (July 12, 1989). For an instance of the confusion and controversy over implementation of court decisions, see Zhang Yulu, "Gai an ershenfayuan ying shiyong zhiding guanxia" (The appeals court should assign suitable jurisdiction), Fazhi Ribao, April 3, 1989, p. 3.

19 See, for instance, "Changde shi zhongshi renmin fayuan jiben jianshe" (Changde city pays attention to the establishment of basic people's court), Fazhi Ribao, May 28, 1990, p.
3. Changde city, Hunan province, has 2 precfetures with 7 xian, with a population of 6 million and $76 \mathrm{fa}-$ ding, each fading covering 60,000 to 70,000 people. Under the direction of the city Party committee and the city administration, funds were raised from the public to establish additional 65 fading during 1989.

20 See, for instance, in Hebei province: "Shijiazhuang tiqu zhongji fayuan kaiban 'shuyin fading' fangbian qunzhong" (Shijiazhuang prefecture middle-level courts hold 'small courts under the trees' for convenience of the masses), Fazhi Ribao, April 20, 1990, p. 1; in Shandong province, Weifang city: "Weifang babai faguan shenru jiceng jie nanti" (Eight hundred judiciary officials from Weifang go down to solve difficult problems at grassroots), Fazhi Ribao, May 17, 1990, p. 3; in Hebei province, Luan county: "Xiang tangfading jiji jiejue cunzhong 'gaozhuang nan'" (Towards the main small court moving to resolve speedily people's complaints of difficulties), Fazhi Ribao, March 4, 1989, p. 3.

21 "Renmin tiaojie zuzhi tiaoli (Regulation on the organisation of People's Mediation Committees) (Issued by the State Council on June 17, 1989). This replaces "Renmin tiaojie weiyuanhui zanxing zuzhi tongze" (General rules for the preliminary organisation of People's Mediation Committees) (Issued by the Government Administration Council, the PRC Central People's Government on March 22, 1954). On the 1954 regulation see Wu Lei, ed., Renmin tiaojie gongzuo jiben zhishi (Basic knowledge of the work of people's mediation) (Shanghai: Shanghai renmin chubanshe, 1986). On the 1989 regulation see, for instance, $\mathrm{Si}$ Qi, "Zai gaige zhong fazhan, chuangxin, wanshan de renmin tiaojie zhi- 
du" (During reform, developing, blazing of new trails, perfecting the system of people's mediation), Fazhi Ribao, July 15, 1989, p. 3; Xiao Sheng, "Renmin tiaojie weiyuanhui zuzhi tiaoli gaishu" (General review of the regulation on the organisation of People's Mediation Committees), Fazhi Ribao, August 16, 1989, p. 3; Li Chunlin, Renmin tiaojie shouce (Handbook on people's mediation) (Beijing: Beijing chubanshe, 1989).

22 Zhang Yin, "Lüelun renmin jiancha yuan de falü jiandu zhineng" (Brief discussion on the supervisory and control functions of the People's Procuratorate), Fazhi Ribao, May 17, 1989 , p. 3.

23 "Guanyu jiancha jiguan kaizhan fan tanwu, huilu douzheng qingkuang de baogao" (Report on the situation regarding the fight against corruption and bribery by procuratorial organs) (Liu Fuzhi, Head, Supreme People's Procuratorate, to the tenth session of the Standing Committee of the Seventh National People's Congress, October 25, 1989).

24 Anecdotal evidence of the lawless behaviour on the part of local cadres can be cited, itself drawn from the local media. At the same time it needs to be noted that the local media also carry accounts of the working of the law, penalising the cadres; see, for instance, Wu Hehu, " 'Nongmin gao xian fu' baisu shimo" (Full account of the loss of a legal case of farmers' complaint against the county administration), Zhongguo Shuili, No. 5, 1989, pp. 25-28; No. 6, 1989, pp. 31-33; No. 7, 1989, pp. 3031, p. 29 . The case involves some rural households (including three Party members) putting up structures impeding water flow and flood control. The account of the judicial processes indicates that they are not without impact and, unusual in the
PRC, the laws invoked are cited: at first the appeal of the households against the administration to the Party and the Party, through the 'letter and visit system' investigating and educating the households on the social consequences; the households approaching the Village People's Committee and the Committee's refusal to interfere with higher-level decision; the local, provincial and national press taking up the cause of the households; the appeal to the People's Economic Court for compensation and the final decision by the Provincial People's Court in favour of the local administration, without compensation to the households, for dismantling the structures.

25 "Zhonghua Renmin Gongheguo xingzheng susong fa (The PRC law on administrative litigation procedure) (Approved by the Seventeenth National People's Congress on April 4,1989 at its second session). Also see Wong Hanbin, "Guanyu Zhonghua Renmin Gongheguo xingzheng susong fa (caoan) de shuoming (Explanation of the draft PRC Law on administrative litigation procedure) (Wong Hanbin, Vice-chairman, Standing Committee of the National People's Congress, at the second session of the Seventh National People's Congress on 28 March 1989). For the debate on the provisions see the report by Wang Hanbin: "Diqijie quanguo renmin daibiao dahui falü weiyuanhui guanyu liangge falü caoan shenyi jieguo de baogao (The report on the results of the deliberations on two draft laws at the legal committee of the Seventh National People's Congress) (April 1, 1989; "Xiugai hao zhebu 'mingao guan' fa" (Reform well the law on people going to law against the government), Fazhi Ribao, February 10, 1989, p. 3 . 
26 Even within the confines of this paper some illustrative contributions to the debate on the 1989 Law need to be noted. At a general level: Meng Xianfei, "Xingzheng sugong zhong de falü shiyong" (Application of law in administrative litigation cases), Faxue Yanjiu, No. 6, 1989, pp. 10-15. On the relationship of the 1989 Law to others: Jiang Ming'an and Liu Fengming, "Xingzheng sugongfa lifa de ruogan wenti yanjiu" (Research on some issues in legislating administrative litigation procedure law), Falü Xuexi yu Yanjiu, No. 3, 1988, pp. 16-19, No. 4, 1988 pp. 2933. On judicial procedures: Xu Ruibai, "Woguo xingzheng sugong zhong de hefa shencha yuanze" (Principles of legal investigation in administrative litigation in our country), Fazhi Ribao, September 15, 1989, p. 3; Zhao Yuanfang, "Lun biange minshi shenpan fangshi ying zhuyi de wenti" (Questions which must be stressed in transforming the ways of bringing to trial civil cases), Fazhi Ribao, November 15, 1989, p. 3 ; Huo Zhen, "Jianli yu shensu falu xingzhixiang shiying de jixiang zhidu" (Useful systematic principles in constructing lawful appeals), Fazhi Ribao, June 30, 1989, p. 3; Chen Weixin, "Tan xingzheng sugong zhengju wenti" (Discussion of issues in testimony in administrative cases), Fazhi Ribao, July 19, 1989, p. 3. On the role of the People's Procuratorate: Wang Guiwu, "Shilun jiancha jiguan zai minshu sugong de falu diwei" (Preliminary discussion of the legal status of the People's Procuratorate in civil cases), Zhengfa Luntan, No. 3, 1989, pp. 32-37, 31. On compensation: Gu Angran, ."Xingzheng sugong zhong de qinquan peichang zeren" (Responsibility for compensation in violation of rights in administrative cases), Fazhi Ribao,
July 8,1989 , p. 3. On administration's rights and responsibilities: $\mathrm{Hu}$ Jiansen, "Lun woguo xingzheng jiguan zai zhifa huodong zhong de zhuti zige" (The principal attributes of our country's administrative organs in enforcing law), Weiding Gao, No. 6, 1989, pp. 16-19.

27 "Guowuyuan guanyu guanche shishi Zhongguo Renmin Gongheguo xingzheng sugongfa de tongzhi (State Council announcement on fully implementing the PRC Administrative Procedure Law), (January 1, 1990).

28 "Renmin jianchayuan zhijie shouli de qinfan gongmin minzhu quanli renshen quanli he duzhi anjian lian biaozhun de guiding" (Regulation specifying requirements for direct handling by the People Procuratorate in accepting and hearing cases on infringement of personal rights or negligence of duties) (Adopted at the 27th session of the seventh meeting of the Procuratorial Committee of the Supreme People's Procuratorate, January 25, 1990).

29 For instance, Zhongguo falü nianjian 1989, pp. 662-686.

30 Mao Zedong, "Yijiusiwunian de renwu" (The task for 1945), Jiefang Ribao (Yan'an), December 16, 1944.

31 See, for instance, Liao Jinbi, "Dangnei piping he ziwo piping de xianzhuang, zhengie ji duice" (The present status of criticism and self-criticism within the Party, the crux of the problem and the way of dealing with it), Dangzheng Luntan, No. 9, 1988, pp. 38-42; Qian Hongcun, "Piping he ziwo piping yu congyan zhidang" (Criticism and self-criticism and strict management of the Party), Shishi Qiu Shi, No. 3, 1988, pp. 44-46. For perceptions, as currently viewed, of the misuse of the system in the past and of present policies for its working see Lu Guang, Piping yu 
ziwo piping de zai renshi (Understanding again criticism and self-criticism) (Yangzhou: Jiangsu renmin chubanshe, 1988).

32 For instance see Qian Xiaobian, "Bixu tuijin he jiakuai dangneide minzhuhua jincheng" (The process of democratisation within the Party must be carried forward and accelerated), Gongren Ribao, February 24, 1989, p. 3; Wu Kaisheng, "Lun dangnei minzhu zhidu de jianshe" (On establishing a democratic system inside the Party), Zhongnan Minzu Xueyuan Xuebao, No. 4, 1989, pp. 118-123. For a model example, see Zhonggong Zhejiangwei zuzhibu, "Zhejiang sheng Jiaojiang shi dangnei zhidu gaige de changshi" (An attempt at reforming internal Party structure in Jiaojiang city in Zhejiang province), Qiushi, No. 6, 1989, pp. 34-36.

33 See Copenhagen Papers in East and Southeast Asian Studies, No. 5, 1990, p. 134, note 13.

34 For fuller details see Sun Weiben, ed., Zhongguo gongchandang dangwu gongzuo da cidian (Comprehensive dictionary on the Chinese Communist Party affairs) (Beijing: Zhongguo zhanwang chubanshe, 1989), pp. 221292; Wang Zhenchuan, Li Zhongcheng, eds., Dangwei shuji bibei ( $R$ equired reading for party committee secretaries) (Beijing: Hualing chubanshe, 1990), pp. 327-370.

35 Zhongyang jilü jiancha weiyuanhui, "Dangde jilü jiancha jiguan anjian shenli gongzuo tiaoli" (Regulation on the work of the Party Disciplinary Commission organs in hearing cases), (July 14, 1987).

36 See, for instance, Tu Shiyi, "Lüelun zhizhengdang de dangnei jiandu" (Brief discussion of internal inspection in the ruling party), Guangxi Dangjiao Xuebao, No. 3, 1988, pp. 4447; Liu Shangyang, "Guanyu jiaqiang dangnei jiandu wenti de tantao"
(Inquiry into the question of strengthening supervision inside the Party), Jiangxi Shehui Kexue, No. 1, 1988, pp. 121-125. "Yifen zhenfen renxin de baogao" (A hard-headed forceful report), Liao Wang, No. 25, 1988, p. 9.

37 "Zhonggong zhongyang jilü jiancha weiyuanhui guanyu gongchandangyuan weifan shehuizhuyi daode dangji chufen de ruogan guiding" (Some directives issued by Party Discipline Inspection Commission on Party disciplinary measures to be meted out to members who violate socialist moral ethics) (November 28, 1989). Acts of violation of socialist ethics include, in addition to the misuse of office for personal gains, the holding of wasteful and extravagant ceremonies, failure in family maintenance and children's education, slandering, hooliganism, adultery, sexual harassment and sexual relationship with another directlyrelated family member. The list can be viewed as an inadvertent clue to the cadres' current behaviour; it is also an indication of the Party's seriousness in forging relationship with the masses and continuing its vanguard role.

38 See, for instance, Cai Fu, "Qianyi jianchi Gongchandangyuan biaozhun wenti" (Simple discussion on the issues in upholding Party members' standards), Lilun Tantao, No. 3, 1988, pp. 58-61.

39 For details see "Guojia dang'anju guanyu jinyibu jiaqiang dang'an shiye jianshe de baogao" (Report by the National Dossier Office on further strengthening the establishment of dossier work) (November 30 , 1989).

40 See, for instance, Liu Yuexian, "Dang de huodong jingfei yinggai zhubu duli" (Funds for Party activities should gradually be self-based), Weiding Gao, No. 6, 1989, pp. 58-59. 
"Dangfei shouna guanli shiyong wenti bushao" (Many issues in collection management and utilisation of Party membership fees), Fazhi Ribao, April 20, 1989, p. 1.

41 See Zhongguo renmin yinhang renshishi, Renshi gongzuo wenjian xuebian (Selected documents on personnel work) (Zhongguo jinrong chubanshe, 1985), p 398.

42 "Zhong jiwei dierci quanhui bimu" (Second plenary session of the Central Disciplinary Commission concluded), Renmin Ribao, March 23, 1989, p. 1.

43 Zhonggong jiwei yanjiushi, "Yange zunshou dangde zhengzhi jilü" (Strictly observe Party's political discipline), Qiushi, No. 13, 1989, pp. 10-14; Zhonggong jiwei yanjiushi, "Kefu sixiang zhang'ai jianjue chengzhi fubai" (Overcome thought barriers, severely punish the corrupt), Qiushi, No. 17, 1989, pp. 30-34; "Quanguo dangyuan yu 4800 wan" (In the whole country Party members exceed 48 million), Renmin $R i$ bao, September 28, 1989, p. 3.

44 "Quanguo guangfan kaizhan minzhu kaoping lingdao ganbu gongzuo" (Throughout the country widespread launching of democratic evaluation of leading cadres' work performance), Zhongguo Fazhibao, July 18, 1987, p. 1.

45 Among the innumerable reports see, for instance,"Xiang, cun ganbu ying zuo lianjie de biaoshuai" (Village cadres should be model for honesty), Sichuan Nongcunbao, April 9, 1989, p. 2; "Canyu lianzheng jiandu shoudao qunzhong chengzan" (Participation in supervision for honest administration wins mass acclaim), Sichuan Nongcunbao, November 3, 1989, p. 1; "Yaoqiu dangyuan ganbu zuodao 'shi qingchu'" (Demand on Party cadres for 'ten understandings'), Sichuan Nongcunbao, October
11. 1989 , p. 1.

46 "Zhonggong Zhongyang guanyu jiaqiang dang tong renmin qunzhong lianxi de jueding" (Central Committee's decision on strengthening the links between the Party and the masses) (March 12, 1990).

47 For relevant regulations see Guowuyuan, "Guanyu weihu xinfang gongzuo zhixu de jixiang guiding" (Some decisions on ensuring orderly letter and visit work) (August 22, 1980). Also, "Dangzheng jiguan xinfang gongzuo tiaoli" (Regulations on Party-administration organs' letter and visit work) (As amended at the Third National Letter and Visit Work Conference, February 21-28, 1982).

48 For details see, for instance, Chai Yin, "Ruhe cengqiang nongmin dangyuan de ningjuli" (How to strengthen the bond between Party members and the rural people), Litun Jiaoyu, No. 4, 1988, p. 42.

49 For details see Zhang Quanjing, ed., Ganbu renshi gongzuo gaishu (General account of cadre personnel management) (Jinan: Shandong renmin chubanshe, 1988), chapter 15, pp. 240265.

50 For a recent interesting discussion of 'local assemblies', without references to the 1986 Law on Local People's Congress, see John P. Burns, Political Participation in Rural China (Berkeley and Los Angeles: University of California Press, 1988).

51 For instance, see "Woguo minzhu xuanju zhidu gengjia wanshan gedi zhijie xuanju xian cun renda daibiao" (Our country's democratic election system increasingly perfecting direct election to every county and village people's congress), Renmin Ribao, March 24, 1987, p. 4; "Xian cun renda huanjie xuanju jinzhan shunli" (Key links in election to county and village people's congress advance smoothly), Renmin Ribao, September 
30, 1987, p. 4; "Quanguo xian cun renda huanjie xuanju jiben wancheng" (In the whole country the basic links in county and village people's congress election basically completed), Renmin Ribao, January 10, 1987, p. 1.

52 For an account of the proceedings and decisions see Quanguo renda changweihui bangongting yanjiushi (bian), Lun renda jiqi changweihui de jiandu quan (Supervisory power of the people's congress and its standing committee) (Beijing: Falü chubanshe, 1988). For illustrative details on the working of the local people's congress at and below xian level, see Sichuan sheng renda changweihui yanjiushi (bian), Difang renda jianshe yanjiu (Research on the establishment of local people's congress) (Sichuan: Guoying jianyangxian yinshuchang, 1986); Difang renmin daibiao dahui zhidu yanjiu ketizu, Difang renmin daibiao dahui jianshe yanjiu (Research on the establishment of local people's congress) (Chengdu: Sichuan Academy of Social Sciences, 1987).

53 Part I, note 27, p. 136. For a commentary on this law see Yang Quanming, ed., Bayi nongminde zhonsyao falü (Important law of 800 million rural people) (Pixian: Sichuan daxue chubanshe, 1988).

54 See, for instance, Tu Wei-ming, "The Rise of Industrial East Asia: The Role of Confucian Values," Copenhagen Papers in East and Southeast Asian Studies, No 4, 1989, pp. 81-97.

55 Lucian W. Pye, The Mandarin and the Cadre: China's Political Cultures (Ann Arbor: Michigan Monographs in Chinese Studies, Vol 59, 1988).

56 Andrew G. Walder, Communist Neotraditionalism Work and Authority in Chinese Industry (Berkeley: University of California Press, 1986). This study is notable for its empirical basis.
57 A select list should include Vivienne Shue, The Reach of the State (Stanford: Stanford University Press, 1988); Jonathan Unger, "State and Peasant in Post-Revolution China," The Journal of Peasant Studies, No. 2, 1989, pp. 114-136; Jean C. Oi, State and Peasant in Contemporary China (Berkeley and Los Angeles: University of California Press, 1989); Anita Chan, Richard Madsen and Jonathan Unger, Chen Village (Berkeley and Los Angeles: University of Californis Press, 1984); David Zweig, Agrarian Radicalism in China, 1968-1981 (Cambridge: Harvard University Press, 1989). Jonathan Unger, "Life in the Chinese Hinterlands," Bulletin of Concerned Asian Scholars, No. 2, 1990, pp. 4-18. Kjeld Erik Brødsgaard, "Party Reform in Post-Mao China," in The Master Said: To Study and...To Søren Egerod on the Occasion of His SixtySeventeenth Birthday (Copenhagen: East Asian Institute Occasional Papers, No. 6, 1990), pp. 67-76.

58 In addition to the detailed discussion in Anita Chan et al., Oi, Walder and Zweig, also see Jonathan Unger, "The Hongkong Connection: The Advantages of China Research from the Room Next Door," China Information, Vol. 11, No. 1, 1987, pp. 2735; Elisabeth Croll, "Short-term Field Investigation in China: A Personal View," China Information, Vol. 11, No. 1, 1987, pp. 17-26. The justification, with minor differences in nuance, runs in terms of representativeness of the sample, profiles of the interviewees, apolitical nature of the interviewees, assurances given of anonymity, cross-checking of the responses and, presumably, the linguistic mastery of the authors, particularly of the local dialects. For the author of this paper the jury is still out. 